\title{
ECG Evaluation Not Performed Due to Corrupted Digital ECG File
}

National Cancer Institute

\section{Source}

National Cancer Institute. ECG Evaluation Not Performed Due to Corrupted Digital ECG

File. NCI Thesaurus. Code C114181.

A digital electrocardiog raphic recording which is corrupted (i.e. ECG signal cannot be restored) such that measurements and/or interpretation cannot be performed. (CDISC) 